DOI 10.37882/2500-3682.2021.05.14

\title{
ПАРАДИГМА СООТНОШЕНИЯ ВЕРЫ И ЗНАНИЯ В НЕМЕЦКОЙ ФИЛОСОФСКОЙ ТРАДИЦИИ (А. ШОПЕНГАУЭР, Л. ФЕЙЕРБАХ, К. МАРКС)
}

\section{THE PARADIGM OF THE RELATIONSHIP BETWEEN FAITH AND KNOWLEDGE IN THE GERMAN PHILOSOPHICAL TRADITION (A. SCHOPENHAUER, L. FEUERBACH, K. MARX)}

T. Izvekova

Summary: The main research tasks solved in this work are the following: a) historical and philosophical analysis of the origin and development of the main philosophical and scientific ideas-from Schopenhauer to Marxabout the problem of the relationship between faith and knowledge, the role and significance of these spiritual principles in the life of man and humanity; b) the search for a single fundamental basis for the implementation of such a theoretical and methodological classification of most of these ideas, which will reveal the basic spectrum of the main cognitive traditions (paradigms) in solving this problem.

Keywords: religion, philosophical anthropology, worldly and transcendental principles, materialism, bourgeoisie, social revolution.
B оззрения немецкого философа А. Шопенгауэра, касающиеся проблемы соотношения веры и знания, неразрывно связаны с положениями его философской системы, пронизанной, как известно, началами волюнтаризма, пессимизма и иррационализма. Опираясь на учение Канта, в своем основном труде «Мир как воля и представление» [4] Шопенгауэр строит свою авторскую концепцию мира, доказывая, что окружающий людей мир является не только итогом их собственных представлений, не только зависит от познавательных способностей самих субъектов, но вообще есть не что иное, как целостный итог активности мировой воли. Если у Гегеля в его философской системе центральное место занимает Абсолютная Идея, то у Шопенгауэра темная Воля.

По Шопенгауэру, мир, состоящий из различных взаимодействующих тел, находящихся в непрерывном потоке различного рода движений, есть единство волевых актов субъектов и действий их тел: всякое действие тел есть объективированный акт воли, в силу чего все тела - это всего лишь та или иная объективированная воля, причем воля в мире является инвариантом внутренней сущности не только органической природы (животных и людей), но и явлений неорганической природы - фи-
Извекова Татьяна Федоровна к.филол.н., дочент, ФГБОУВО «Новосибирский государственный медицинский университет»

Минздрава России

izvekova01@gmail.com

Аннотация: Главными исследовательскими задачами, решаемыми в данной работе являются следующие: а) историко-философский анализ зарождения и развития основных философских и научных представлений - от Шопенгауэра до Маркса - о проблеме соотношения веры и знания, роли и значимости этих духовных начал в жизни человека и человечества; б) поиск единого фундаментального основания для осуществления такой теоретико-методологической классификации большинства этих представлений, которая позволит выявить базовый спектр основных познавательных традиций (парадигм) в решении этой проблемы.

Ключевые слова: религия, философская антропология, мирское и трансцендентальное начала, материализм, буржуазия, социальная революция.

зических, химических, геологических и др. процессов. В качестве ярких примеров воли в неорганической природе философ приводит силу всемирного тяготения, открытую И. Ньютоном, и силу магнитного взаимодействия; все эти силы, по Шопенгауэру, различны в своих проявлениях, но имеют одну и ту же внутреннюю сущность - ею как раз и является феномен воли. Философ утверждает, что воля как «вещь в себе» совершенно независима от своих форм проявлений, ничем не обусловлена и не ограничена, не имеет каких-либо оснований или причин. В этих своих свойствах воля принципиально отличается от материи, которая всецело подчинена причинности и взаимосвязи всего со всем. Согласно представлениям Шопенгауэра, главное предназначение воли в мире - осуществление полного господства над материей, для чего волевое начало готово тысячелетиями ожидать необходимых условий и обстоятельств для полного овладения тем или иным материальным феноменом. Мировая воля представлена в форме множества отдельных воль, находящихся в непрерывной борьбе друг с другом; на низшей ступени развития (в природе) воля проявляет себя в форме слепого влечения, как некий темный и глухой порыв. Однако на более высоких ступенях своего развития, особенно на уровне человека, воля предстает уже как вполне осознанная идея ин- 
дивида, который имеет и определенные мотивы для ее воплощения в реальность. Поскольку волевому началу присуще свойство его безосновности, оно находит свое основное проявление в явлении определенной свободы человеческой воли; свобода, в свою очередь, сразу предстает и в своем противоположном качестве - как господствующая в мире необходимость, поскольку борьба отдельных воль - это столкновение не только разных целей действий, их мотивов, но и различных материальных объектов, вовлеченных в эти действия; следовательно, свобода переходит в необходимость, являясь фактически выражением обязательной подчиненности причинности, господствующей в материальном мире. В силу того, что воля обладает еще и свойством бессознательности, она совершенно равнодушна ко всем своим формам проявлений в мире, например, к живым существам, в том числе к людям; именно из этого положения его философии вырастает особый, трагический по своей сути феномен глубокого пессимизма всей его философии - ведь, по утверждению Шопенгауэра, люди как наиболее совершенные воплощения мировой воли брошены ею на произвол случайно складывающихся обстоятельств и факторов, тотально вовлечены в абсолютно безнадежную и смертельную борьбу за существование со всем ему противостоящим миром. Жизнь человека есть непрерывная война со смертью в разных ее вариантах и обличиях и фактически жизненный процесс есть процесс непрерывного умирания; с одной стороны, человек - самое совершенное творение мировой воли, а с другой - самое нуждающееся, самое страдающее существо в мире, вынужденное постоянно сражаться с одними страданиями и лишениями для того, чтобы сразу же после этого оказаться в ловушке других, еще более чудовищных своей трагичностью факторов и обстоятельств. Над любым человеком всегда полностью господствует только одна сила - необходимость в постоянной заботе о своем существовании, для чего человек вынужден постоянно вести свою настоящую войну против себе подобных, включая даже убийства - ведь мир устроен так, что один человек утверждает свое присутствие в мире, не гнушаясь физического отрицания права на жизнь другого человека. Злоба, эгоизм, несправедливость, жестокость, ненависть, страх - неизбежные плоды войны всех против всех, тысячелетия длящейся в этом мире. Шопенгауэр не видит никакого особого прогресса в развитии человеческого общества, считая, что о нем можно вести речь, главным образом, не от начал материальных благ, получаемых от науки и техники, а от все более возрастающих начал моральности любого прогресса, которых, к сожалению, как раз и нет вовсе.

Самое печальное, по Шопенгауэру, и то обстоятельство, что человеческий разум, на который было столько надежд и упований, не способен привести мир в более лучшее состояние; в этом отношении теория познания Шопенгауэра также пессимистична, как и вся его фило- софия - ведь по его убеждению истинная сущность мировых вещей и процессов принципиально иррациональна по своему характеру и поэтому разум в их познании мало что может; подлинное постижение мировых законов и принципов доступно только иррациональной философской интуиции - запредельной познавательной воле. Более того, Шопенгауэр считает, что познание лишь увеличивает наши страдания бытия, поскольку то, что мы пытаемся считать истиной, в конечном своем развитии оказывается не боле, чем обманом и иллюзией.

Вера у Шопенгауэра - тоже иррациональна, причем еще более, чем разум (знание). Самой лучшей из всех религий Шопенгауэр считает буддизм - религию без Бога, причем с принципиально пессимистический направленностью: буддизм смотрит на мирское существование человека как на зло, нацелен на отрицание такого мира. Также пессимистичны учения Шопенгауэра о человеке, свободе человеческой воли, добре и зле, счастье и смысле человеческой жизни, которая философу представляется сплошным адом; однако изменить такое положение дел в мире принципиально невозможно, поскольку, по Шопенгауэру, свобода воли людей опутана их же собственными нуждами и потребностями [5]. По своему содержанию мировая воля есть зло, поскольку она стремится к подчинению всего, что препятствует ее господству. В силу этого закон мотивации активности людей действует с такой же необходимостью и жесткостью, как и закон физической причинности. Шопенгауэр убежден, что человеку только кажется, что он поступает согласно импульсам собственной воли - на самом же деле любой человек движим и управляем мировой волей - единственным для всех подлинно-значимым и господствующим фактором. В таком мире людям не остается никакого иного выбора в построении своей короткой как миг жизни, кроме того, чтобы прожить ее без особых бед, которые совершенно неизбежны, самому держать в узде свои собственные страсти и всегда самостоятельно ставить предел своим желаниям.

Таким образом, из анализа основных положений философии Шопенгауэра можно сделать вполне определенные выводы относительно его концепции решения проблемы соотношения веры и знания. Самый главный вывод состоит в том, что эти два начала в его философии не носят весомого и определяющего характера, находятся фактически на периферии его философских исканий. Вся суть философии Шопенгауэра сосредоточена в одном-единственном начале - в мировой воле, по отношению к которому и разум (знание), и вера людей - начала достаточно второстепенные, к тому же обладающие принципиально иррациональной своей сущностью, в силу чего абсолютно непостижимы с помощью веры и разума (знания). Такое концептуальное решение одной из главных мировых проблем - взаимосвязи веры и знания, в котором эти два начала вытесняются из категории 
главных и существенных для философских систем более важным третьим началом - предложено Шопенгауэром впервые.

Иначе говоря, именно Шопенгауэр - тот первый философ в мировой философии, который усомнился в первостепенной значимости проблемы соотношения веры и знания, в силу чего отказался строить свою философскую систему в опоре на то или иное ее решение.

Взгляды Л. Фейербаха [6] на проблему соотношения веры и знания тоже важны для данного исследования; это и неудивительно, поскольку его философия напрямую затрагивает этот фундаментальный вопрос, причем достаточно неожиданным образом, о чем следует здесь особо подчеркнуть - это обстоятельство важно и для понимания самой сущности творчества и жизни Фейербаха [1]. Известно, что одна из ранних его работ - «Мысли о смерти и бессмертии», написанная им анонимно еще как студентом, отрицала личное бессмертие человека и его загробную жизнь. В начале своего творчества Фейербах был увлечен философией Гегеля, но в течении нескольких лет его теоретические воззрения радикально изменились настолько, что он стал жестко критиковать основные положения гегелевской философии, в первую очередь за их идеализм. Фейербах решительно выступает против Гегеля в вопросе о тождестве бытия и мышления, утверждая, что Гегель спекулятивно строит свою философскую систему изначально от абстрактного (идеального) бытия, совершенно ничего не сказав в своих теоретических построениях о бытии реальном (материальном) - ему в философии Гегеля места вообще не нашлось. Да и принцип единства бытия и мышления будет иметь смысл лишь тогда, когда субъектом этого единства является человек - таково основное положение философии Фейербаха. Только тогда этот принцип может быть применен, но тогда получается, что вопрос об отношении мышления к бытию есть на самом деле вопрос о человеке: «Новая философия превращает человека, включая и природу как базис человека, в единственный, универсальный и высший предмет философии, превращая, следовательно, антропологию ... в универсальную науку» [6]. Не согласен Фейербах с Гегелем и в вопросе о главном предмете философии: по Фейербаху, высший и единственный предмет философии - только человек, а вовсе не Абсолютный дух, как у Гегеля. Отсюда жесткая критика религии [7], которая становиться главным сюжетом всего философского творчества Фейербаха. По его взглядам, религия - социокультурный феномен исключительно от самого человека, его собственная духовная сущность, обособленная от человека в качестве отдельного самостоятельного существа - Абсолютного духа, или Бога. На самом деле Бог - это сам человек, а религия по своему содержанию является фактически антропологией: она - о глубинах человеческой психики, о преодолении конечности собственной жизни, о ничтож- ном и бессильном положении человека в этом мире. Все эти человеческие, чисто психические, начала, и есть сущность веры - духовного феномена существования и развития человека.

Согласно воззрениям Фейербаха, человеку следует преодолеть противопоставление мирского и трансцендентального начал своей жизни и решительно заняться созданием «царства Божьего» на земле: по Фейербаху, нужны люди не верующие, а думающие, не бесконечные спекуляции о потустороннем мире, о котором человек ничего не может знать, а научные знания о реальном мире; не молящиеся, а работающие; не стремящиеся в занебесье, а изучающие мир посюсторонний, не христиане (он их называет «полуживотными и полуангелами»), а подлинные люди во всем своем реальном обличье.

Анализируя решение проблемы соотношения веры и знания в контексте основных теоретических воззрений К. Маркса [3], следует сразу отметить, что он ее решает не только как философ, но еще как экономист и как социолог. Такой принципиально-многоплановый дискурс Маркса в решении исследуемых им вопросов не мог не привести его к целому ряду принципиально новых аспектов ее решения; покажем это в краткой форме анализа его самых фундаментальных положений. Центральная направленность всего творчества Маркса хорошо известна и стала уже подлинной классикой в постижении сути его учения [1] - это возможности и способы совершенствования человечеством самого себя путем активного создания нового социального строя - более справедливого, свободного, неантагонистического, бесклассового, общества, в котором публичная власть потеряет свой политический характер, а централизованное управление средствами производства перейдет к ассоциации индивидов. Такое общество будет построено на основе централизованного управления средствами производства, а частная собственность, капитал, наемный труд будут раз и навсегда упразднены. В основе такого рода теоретических построений Маркса о сущности общества и законах его развития лежит его основная идея [1] - с помощью философских, социологических, экономических, политических, других научных знаний (опираясь, например, на достижения естественных наук - физики, химии, биологии, геологии и т.д.) добиться построения целостной и системной теории общества и тем самым открыть его принципиально-объективные (как в естествознании) законы и принципы развития.

С точки зрения Маркса, такую объективную сторону всех общественных процессов и явлений позволяет вскрыть научное исследование, прежде всего, экономических структур общества, в которых решающим феноменом, по Марксу, выступают антагонистические противоречия между предпринимателями и рабочими, которые мыслитель вообще считал самым главным 
фактором социальных изменений. Опираясь на эти объективные, по Марксу, научные знания об обществе, можно целенаправленно и активно осуществлять строительство нового социального строя, в том числе путем осуществления пролетарской революции - впервые в мировой истории революции большинства (пролетариата) против меньшинства (буржуазии). Маркс убежден, что победа пролетариата над буржуазией - неизбежна, является объективным законом развития любого человеческого общества, в силу которого на место старого буржуазного социального строя с его классами и классовой борьбой придет ассоциация свободных индивидов, в которой «свободное развитие каждого является условием свободного развития всех». В этом контексте общественная теория Маркса постепенно начинает выполнять функцию религии как некое учение, базирующееся на твердой вере в то, что новый общественный строй («рай на земле») может быть построен с помощью определенных социальных изменений, в том за счет принципиально-насильственных действий одной части общества по отношению к другой (пролетарская революция). Как самый настоящий атрибут новой религии выглядит в учении Маркса и пролетарский мессианизм - полный аналог мессианизма христианского; отсюда вполне логичен вывод о том, что не менее значимым началом, кроме научного знания для Маркса, как видно из вышесказанного, выступает и начала особой веры веры в объективность экономических аспектов развития общества, веры в обязательное наличие для общества таких же независимых от воли человека законов социального развития, как и законы естествознания для природы, веры в непреложность победы нового соци- ального строя над старым, веры в историческую миссию пролетариата и др. Эта вера в одних случаях подкрепляется наличием определенных научных знаний, но целый ряд положений теории Маркса об общественном развитии - это все же только «чистые» феномены веры (выше мы некоторые из них обозначили).

Итак, проблема соотношения веры и знания Марксом трактуется как их безусловное единство, причем ведущую роль в нем играет именно научное знание, поскольку вера как самостоятельное начало в явной форме в воззрениях Маркса фактически не присутствует, все положения его учения строятся исключительно из научного знания. Хотя веру, связанную с религией, Маркс, как известно, отвергает, но парадокс состоит в том, что само его учение фактически превращается в новую религию, в которой главные положения становятся самыми настоящими догматами - непреложными истинами по типу известного выражения В.И. Ленина из его статьи «Три источника и три составных части марксизма» [2]: «Учение Маркса - всесильно, потому что оно верно».

В данной статье рассмотрены варианты решения проблемы соотношения веры и знания в философских построениях трех мыслителей - Шопенгауэра, Фейербаха и Маркса; анализ их воззрений показал, что хотя и по-разному, но в их теоретических построениях исследуемая проблема присутствует даже тогда, когда в явном виде ее нет (речь идет о взглядах Шопенгауэра, в которых вера и знание не носят весомого и определяющего характера, поскольку суть его философии сосредоточена в одном-единственном начале - в мировой воле).

\section{ЛИТЕРАТУРА}

1. История философии: Энциклопедия. Мн.: Интерпрессервис; Книжный Дом, 2002.

2. Ленин В.И. Три источника и три составных части марксизма// Ленин В.И. ППС, 5 изд. Т.23.

3. Маркс К., Энгельс Ф. Из ранних произведений. М.: Государственное издательство политической литературы, 1956.

4. Шопенгауэр А. Мир как воля и представление// А. Шопенгауэр. Собр. Соч. в пяти томах. Том первый. Перевод Ю.И. Айхенвальда под редакцией Ю.Н. Попова. Примечания А.Л. Чанышева. М.: «Московский клуб», 1992.

5. Шопенгауэр А. Сборник произведений / Пер. с нем.; Вступ. ст. и прим. И.С. Нарского; Худ. обл. М. В. Драко. - Мн.: 000 «Попурри», 1999.

6. Фейербах Л. Основные положения философии будущего// Фейербах Л. Избранные философские произведения в двух томах. Т. 1. М., 1955.

7. Фейербах Л. Сущность христианства//Л. Фейербах Избранные философские произведения в двух томах. Т.2., М., 1955.

(с) Извекова Татьяна Федоровна (izvekova01@gmail.com). 